\title{
OBECNOŚĆ ROSYJSKICH SIŁ ZBROJNYCH NA OBSZARZE NADDNIESTRZA W DRUGIEJ DEKADZIE XXI WIEKU - WYBRANE ASPEKTY
}

\author{
THE PRESENCE OF RUSSIAN FORCES IN THE TRANSNISTRIAN \\ AREA IN THE SECOND DECADE OF THE 21ST CENTURY: \\ SELECTED ASPECTS
}

Agnieszka Miarka* (1)

\begin{abstract}
ABSTRAKT
Celem artykułu jest charakterystyka stanowisk: Federacji Rosyjskiej, Mołdawii i nieuznawanej Naddniestrzańskiej Republiki Mołdawskiej wobec obecności rosyjskich sił zbrojnych na obszarze Naddniestrza oraz motywacja działań podjętych w tej kwestii. W pierwszej części pracy skoncentrowano wysiłki na przedstawieniu genezy powstania państwa nieuznawanego w granicach Mołdawii i znaczenia dla tego procesu formacji rosyjskich. Następnie zaprezentowano podejście zainteresowanych stron do problemu alokacji sił rosyjskich w Naddniestrzu. Ponadto uwzględniono głos szeroko pojętej społeczności międzynarodowej (rezolucja ZO ONZ). Zaakcentowano również uwzględnienie tego zagadnienia w nowej strategii obrony Mołdawii (2018). Za priorytet uznano wydarzenia zaistniałe $\mathrm{w}$ drugiej dekadzie XXI w.
\end{abstract}

Słowa kluczowe: Naddniestrze; obszar poradziecki; siły zbrojne; bezpieczeństwo; Rosja
The aim of the article is to characterize the positions of: the Russian Federation, Moldova and the unrecognized Transnistrian Republic of Moldova against the presence of Russian armed forces in the Transnistrian area and the motivation of actions taken in this matter. In the first part of the work, efforts were concentrated on presenting the origins of the creation of a state not recognized in the borders of Moldova and the significance of this process of Russian formation. Next, there was presented the approach of interested parties to the problem of allocating Russian forces in Transnistria. In addition, the voice of the broadly understood international community (UN GA resolution) had been taken into account. The inclusion of this issue in the new defense strategy of Moldova (2018) was also emphasized. Events in the second decade of the $21^{\text {st }}$ century were considered the priority.

Keywords: Transnistria; post-Soviet area; armed forces; security; Russia

* Uniwersytet Śląski w Katowicach, Wydział Nauk Społecznych. 


\section{WSTĘP}

Funkcjonowanie państw nieuznawanych stanowi wyzwanie dla całej społeczności międzynarodowej. Jednym z przykładów takiego podmiotu w przestrzeni poradzieckiej jest Naddniestrzańska Republika Mołdawska (NRM). Ten region, przejawiający intensywne tendencje separatystyczne, funkcjonuje od lat 90. XX w. jako terytorium niezależne względem macierzystego państwa, stanowiąc wyzwanie dla utrzymania bezpieczeństwa Mołdawii. Silny wpływ na krzepnięcie państwowości quasi-państwa i jego przetrwanie oraz rozwój w obecnej formie miała Federacja Rosyjska. Ze względu na rosyjską pomoc w postaci m.in. dotacji celowych, subsydiów gazowych, wsparcia dyplomatycznego na arenie międzynarodowej, tyraspolska administracja mogła wzmacniać swoją asertywność w toku rozmów dotyczących uregulowania statusu Naddniestrza i budować swoją odrębność względem Mołdawii (Miarka, 2016). Jednym z przejawów zaangażowania Moskwy w kwestię naddniestrzańską jest obecność rosyjskich sił zbrojnych na tym obszarze. Celem artykułu jest charakterystyka stanowisk zainteresowanych stron: Mołdawii, Federacji Rosyjskiej oraz NRM, motywacji aktywności oraz podjętych działań względem stacjonowania rosyjskich formacji w Naddniestrzu. Ponadto uwzględniono optykę szeroko pojętej społeczności międzynarodowej, której przykładem jest uchwalenie rezolucji ZO ONZ w sprawie wycofania sił rosyjskich z Naddniestrza (2018 r.). Wśród pytań badawczych, na które autorka stara się udzielić odpowiedzi, należy wymienić: dlaczego Federacja Rosyjska nie chce wycofać swoich formacji z Naddniestrza? Jak obecność wojsk rosyjskich postrzegają mołdawscy decydenci? Dlaczego Naddniestrze popiera rosyjską obecność militarną w regionie? Zagadnienie stacjonowania Grupy Operacyjnej Wojsk Rosyjskich zostało wybrane przez autorkę jako temat wiodący artykułu ze względu na jego znaczenie dla bezpieczeństwa Mołdawii oraz potencjalnego rozwiązania kwestii naddniestrzańskiej. Zakres rozważań koncentruje się na drugiej dekadzie XXI w., m. in. z uwagi na zmianę akcentów w polityce Mołdawii i dwutorowe podejście do problemu Naddniestrza po objęciu urzędu prezydenta przez Igora Dodona (2016 r.). Niezwykle pomocne w odpowiedzi na pytania badawcze okazały się analizy i interpretacja aktów normatywnych dotyczących problemu badawczego, jak i oficjalne wypowiedzi czołowych decydentów politycznych Mołdawii i NRM. 


\section{GENEZA POWSTANIA NIEUZNAWANEJ NADDNIESTRZAŃSKIEJ REPUBLIKI MOŁDAWSKIEJ}

Region naddniestrzański położony jest na lewym brzegu Dniestru i zgodnie z ostatnim spisem ludności sporządzonym przez separatystyczne władze liczba ludności wynosi 467 tys. os. Społeczeństwo charakteryzuje następująca struktura etniczna: Rosjanie - 29,1\%, Mołdawianie - 28,6\%, Ukraińcy - 22,9\%, Bułgarzy $-2,4 \%$, Gagauzi - 1,1\%, Białorusini - 0,5\%, inne - 1,4\%, Naddniestrzanie - 0,2\%, brak - 14\% (Perepis' naseleniya PMR, 2015). Obszar ten w znacznym stopniu różni się od pozostałej części Mołdawii: należy zauważyć zdecydowaną dominację ludności słowiańskiej, uprzywilejowaną pozycję języka rosyjskiego w codziennej komunikacji mieszkańców, rosyjską (i radziecką) tożsamość wykazywaną przez ludność Naddniestrzańskiej Republiki Mołdawskiej (NRM), brak więzów z historyczną Besarabią, większym stopniem uprzemysłowienia niż prawobrzeżna Mołdawia.

Intensyfikacja antagonizmów na linii Kiszyniów-Tyraspol miała miejsce w okresie radzieckim po zjednoczeniu prawobrzeżnej i lewobrzeżnej Mołdawii w jeden organizm państwowy - Mołdawską SRR (1940). Przez pierwsze 20 lat funkcjonowania tego podmiotu wśród grupy decydentów politycznych dominowały osoby rosyjskojęzyczne, wywodzące się z lewego brzegu (jak również $\mathrm{w}$ administracji czy wojsku), dlatego język rosyjski stał się wszechobecny w strukturach państwowych. Jest to zasadny zabieg władz centralnych ZSRR ze względu na więzi tożsamościowe Naddniestrza, które były zdecydowanie silniejsze niż prawego brzegu. Często wskazywano na asymetryczność w składach organów centralnych republiki na korzyść elit naddniestrzańskich, co stanowiło czynnik dyskryminujący większość społeczeństwa o orientacji prorumuńskiej. Wraz ze wdrażaniem założeń pierestrojki, czego efektem było osłabienie wpływu Moskwy na elementy składowe, podobnie jak w innych republikach radzieckich, w Mołdawskiej SRR zaczęły pojawiać się tendencje nacjonalistyczne. Już w latach 60. XX w. rozpoczęto proces korienizacji aparatu państwowego (Leont'yeva, Yastrebchak, 2014). Rosnące w siłę stronnictwa nacjonalistyczne podjęły działania ku ograniczeniu obecności elit rosyjskojęzycznych w aparacie państwowym, czego przykładem jest m. in. przyjęcie ustawy językowej przez Radę Najwyższą Mołdawskiej SRR (31 sierpnia 1989 r.), uznając język mołdawski (zapisywany alfabetem łacińskim) za jedyny język urzędowy, natomiast język rosyjski został językiem komunikacji i załatwiania spraw urzędowych mniejszego znaczenia. Tym samym zobowiązano urzędników państwowych do znajomości 
i posługiwania się językiem mołdawskim. Ruchy skupiające ludność słowiańską nalegały, aby przyznać równy status językowi rosyjskiemu i mołdawskiemu, gdyż to byłoby zrozumiałe w odniesieniu do składu etnicznego Naddniestrza. Warto pamiętać, że nie tylko ludność słowiańska posługiwała się językiem rosyjskim, ale i etniczni Mołdawianie mieszkający na tym obszarze w dużej części uważali go za swój język ojczysty (Serzhanova, 2017). Następnie elity prawobrzeżnego obszaru Mołdawskiej SRR zainicjowały kroki ku uniezależnieniu się od coraz słabszej Moskwy. Już 23 czerwca 1990 r. Mołdawska SRR ogłosiła suwerenność, natomiast 28 czerwca mołdawski parlament uznaje pakt Ribbentrop-Mołotow za nieważny, Północną Bukowinę i Besarabię za terytoria okupowane, a utworzenie Mołdawskiej SRR za bezprawny czyn. W reakcji na te decyzje Kiszyniowa oraz opierając się na woli mieszkańców Naddniestrza wyrażonych w lokalnych referendach, nadzwyczajny zjazd deputowanych Naddniestrza ogłosił 2 września 1990 r. powstanie Naddniestrzańskiej Mołdawskiej Socjalistycznej Republiki Radzieckiej, pozostającej w składzie ZSRR (Lubicz-Miszewski, 2012). Ze względu na postępujący proces rozkładu struktur ZSRR zmieniono 5 listopada nazwę na Naddniestrzańska Republika Mołdawska i miesiąc później ogłoszono suwerenność względem ZSRR. Ostatecznie Mołdawia ogłosiła 27 sierpnia $1991 \mathrm{r}$. niepodległość, natomiast 1 grudnia na obszarze Naddniestrza zorganizowano referendum w sprawie niepodległości NRM, w którym wzięło udział 78\% uprawnionych do głosowania mieszkańców. W efekcie aż 97,7\% ludności opowiedziało się za funkcjonowaniem Naddniestrza jako niezależnego państwa (Rezul'taty Referendumov Pridnestrovskoy Moldavskoy Respubliki..., 2014).

Te wydarzenia doprowadziły do wybuchu tzw. wojny pięciomiesięcznej (1992) między zbuntowanym Naddniestrzem a Republiką Mołdawii, która chciała zbrojne spacyfikować nastroje separatystyczne i doprowadzić do reintegracji tego obszaru z państwem. Za najważniejszą operację w toku wojny uznaje się operację Koń trojański, która zakładała zajęcie miasta Bendery, a następnie uderzenie na stolicę parapaństwa, czyli Tyraspol. W ciągu kilku godzin operacji siły mołdawskie sformowane w pięć kolumn zajęły praktycznie całe miasto. Mimo tego ostatecznie stroną dominującą okazało się Naddniestrze, które oprócz wsparcia udzielonego przez wielu bojowników pochodzących z przestrzeni poradzieckiej, licznego zaangażowania Naddniestrzan w ochotnicze formacje paramilitarne, otrzymało również wsparcie od 14. Armii Rosyjskiej stacjonującej w okolicy Benderów jako siły pokojowe. Było to przełomowe dla trwającego od kwietnia oblężenia, gdyż już 20 czerwca udało się odzyskać miasto i zneutralizować siły je okupujące. 
Kiszyniów znajdujący się w niekorzystnym położeniu strategicznym został zmuszony do podpisania zawieszenia broni z Tyraspolem 21 lipca 1992 r., gdyż dalsze prowadzenie działań zbrojnych w tak zmienionych warunkach wojennych (zaangażowanie Federacji Rosyjskiej) nie przyniosłoby żadnych korzyści. W dokumencie podpisanym przez prezydentów Mołdawii (Mircea Snegur) i Federacji Rosyjskiej (Borys Jelcyn) wskazano dążenie do pokojowego rozwiązania konfliktu zbrojnego w regionie Naddniestrza, potwierdzając przestrzeganie zasad Karty Narodów Zjednoczonych i Konferencji Bezpieczeństwa i Współpracy w Europie. Strony konfliktu zostały zobowiązane do podjęcia kroków na rzecz zawieszenia broni oraz wszelkich działań zbrojnych przeciwko sobie, usunięcia sprzętu wojskowego, broni i jednostek wojskowych w ciągu 7 dni, aby można było stworzyć strefę bezpieczeństwa między nimi. Na mocy art. 2 Porozumienia w sprawie zasad pokojowego uregulowania konfliktu zbrojnego w regionie Naddniestrza Republiki Mołdawii powołano Komisję Kontrolną, składającą się z przedstawicieli trzech stron (mołdawskiej, rosyjskiej i naddniestrzańskiej), której zadaniem było utrzymanie bezpieczeństwa we wspomnianej strefie oraz monitorowanie procesu wdrażania warunków zawieszenia broni, siedzibą Komisji ustalono Bendery. Strony zadeklarowały oddelegowanie kontyngentów wojskowych odpowiedzialnych za utrzymanie pokoju w strefie zgodnie z decyzjami podjętymi przez Komisję. Potępiono wszelkie ograniczenia i blokady natury ekonomicznej, Kiszyniów miał podjąć działania na rzecz zniesienia wszelkich mechanizmów ingerujących w swobodny przepływ osób, towarów i usług. Zadeklarowano natychmiastowe rozpoczęcie negocjacji w sprawie powrotu uchodźców do miejsc zamieszkania, udzielenia pomocy ludności dotkniętej skutkami konfliktu oraz odnawiania budynków mieszkalnych (Federacja Rosyjska zobowiązała się do udzielenia pomocy Mołdawii w tej kwestii), niezakłócony dostęp do strefy uregulowania dla międzynarodowej pomocy humanitarnej. Instrumentarium wymienione w porozumieniu miało być częścią zainicjowanego procesu rozwiązania konfliktu na drodze dyplomatycznej (Soglasheniye o printsipakh mirnogo uregulirovaniya vooruzhennogo konflikta v Pridnestrovskom regione Respubliki Moldova..., 1992).

Wojna okazała się porażką Mołdawii - nie udało się przywrócić integralności terytorialnej państwa, wzmocniono tym samym niezależność NRM, która od początku lat 90. XX w. funkcjonuje de facto jako niezależny podmiot posiadający wszystkie atrybuty państwowości (m. in. system polityczny, siły zbrojne, symbolikę państwową, prowadzenie polityki zagranicznej), oraz usankcjonowano obecność rosyjskich sił zbrojnych jako sił pokojowych. Na terytorium 
Naddniestrza pozostały oddziały 14. Armii (tzw. Grupa Operacyjna Wojsk Rosyjskich $^{1}$ ). Ponadto od początku zainicjowania rozmów na rzecz uregulowania statusu Naddniestrza głównym mediatorem była Moskwa, od 1995 r. włączyła się w nie również Ukraina. Od 2005 r. rozmowy prowadzone są w formacie 5+2 (Mołdawia, NRM, OBWE, Rosja, Ukraina oraz obserwatorzy z UE i USA), jednak ich rezultaty nie poskutkowały rozwiązaniem tego istotnego problemu dla bezpieczeństwa Mołdawii.

\section{STANOWISKO MOŁDAWII WOBEC OBECNOŚCI ROSYJSKICH SIŁ ZBROJNYCH W NADDNIESTRZU}

W 2013 r. wspólne siły pokojowe liczyły ok. 1200 personelu wojskowego (402 Rosjan, 492 Naddniestrzan, 355 Mołdawian oraz 10 obserwatorów z Ukrainy jest w szeregach sił pokojowych). Mirotwórcy ulokowani są w 15 punktach kontrolnych i stałych stanowiskach w najważniejszych miejscach strefy bezpieczeństwa rozciągniętej wzdłuż Dniestru na długości $225 \mathrm{~km}$ oraz o szerokości 12-24 km (Novik, 2014). Jak już wspomniano, oprócz mieszanych sił zbrojnych na obszarze Naddniestrza nadal pozostają rosyjskie oddziały (okolice Benderów), co wzbudza kontrowersje wśród proeuropejskich i prozachodnich polityków Mołdawii, konsekwentnie domagających się reorganizacji formatu sił pokojowych oraz wycofania ze strefy konfliktu wojsk rosyjskich. Były prezydent Mołdawii Nicolae Timofti podczas posiedzenia Zgromadzenia Parlamentarnego Rady Europy (2012) wskazywał, że Siły Zbrojne Federacji Rosyjskiej stacjonujące na terytorium Republiki Mołdawii bez zgody państwa przyjmującego oraz wbrew zapisom konstytucyjnym powinny zostać wycofane. Stanowisko Kiszyniowa jest popierane przez Unię Europejską oraz USA. W grudniu 2012 r. amerykańska delegacja wezwała Radę OBWE do zainicjowania dyskusji nad transformacją misji pokojowej w Naddniestrzu. Idea wycofania rosyjskich obserwatorów wojskowych i zastąpienie ich misją cywilną jest również aprobowane przez Bukareszt (Novik, 2014).

Kiszyniów usztywnił swoje stanowisko w tej kwestii w 2017 r. Parlament Mołdawii przegłosował deklarację $\mathrm{w}$ sprawie wycofania sił rosyjskich $\mathrm{z}$ terytorium państwa. Co znamienne, dokument został uchwalony w rocznicę zakończenia wojny pięciomiesięcznej oraz podpisania zasad pokojowego uregulowania konfliktu. We wspomnianej deklaracji stwierdzono, że permanentna obecność rosyjskich sił zbrojnych we wschodniej części Republiki Mołdawii narusza 
zapisy konstytucyjne Republiki, zwłaszcza te dotyczące suwerenności, integralności terytorialnej i statusu neutralności państwa, oraz stanowi wyraźne naruszenie norm prawa międzynarodowego. Wobec tego mołdawski parlament wezwał Moskwę do wznowienia oraz zakończenia procesu wycofywania wojsk $z$ terytorium Naddniestrza oraz usunięcia wszelkiej broni i amunicji. Ponadto wyrażono prośbę, aby rząd i prezydent wsparli wszystkimi możliwymi środkami przyjęcie przez RB ONZ rezolucji w sprawie wycofania rosyjskich wojsk, przebywających nielegalnie na obszarze Mołdawii. Dostrzeżono też potrzebę reorganizacji dotychczasowego mechanizmu pokojowego $\mathrm{w}$ misję cywilną, posiadającą mandat międzynarodowy. Ten krok został zdecydowanie potępiony przez prorosyjskiego prezydenta Mołdawii Igora Dodona, który piastuje urząd od grudnia 2016 r, co wskazuje na brak harmonijnego stanowiska mołdawskiej sceny politycznej względem aktywności Rosji w Naddniestrzu (Miarka, 2018). Proeuropejskie stronnictwa polityczne Mołdawii dostrzegają, że obecność rosyjskich sił zbrojnych wzmacnia niezależność parapaństwa, a tym samym niweluje szybką perspektywę reintegracji tego obszaru z Mołdawią. Nieuregulowany status Naddniestrza stanowi poważną przeszkodę na jej drodze ku partycypacji w strukturach europejskich.

Należy zwrócić szczególną uwagę na stanowisko MSZ NRM, które w odpowiedzi na deklarację mołdawskiego parlamentu opublikowało wyniki badań opinii publicznej, przeprowadzonych od 16 czerwca do 5 lipca 2017 r. Według $92 \%$ przebadanych respondentów obecna operacja pokojowa jest efektywna. Co więcej, obecność sił pokojowych w dotychczasowym kształcie wzmacnia poczucie bezpieczeństwa u 78\% ankietowanych (odpowiedzi „raczej tak” udzieliło 14\% badanych). Również zdecydowana większość (73\%) respondentów stwierdziła, iż wycofanie rosyjskich wojsk nie przyczyni się do rozwiązania konfliktu mołdawsko-naddniestrzańskiego. Przytoczone wielkości jednoznacznie wskazują, że potencjalna realizacja postulatów mołdawskiego parlamentu implikowałaby wzrost niepokojów wśród naddniestrzańskiego społeczeństwa oraz może przyczynić się do dalszej destabilizacji tego regionu, co stanowi bezpośrednie zagrożenie dla bezpieczeństwa narodowego Mołdawii (Miarka, 2018). 


\section{REZOLUCJA ONZ W SPRAWIE WYCOFANIA SIŁ ROSYJSKICH} Z NADDNIESTRZA (2018)

Po eskalacji sytuacji na wschodzie Ukrainny (od 2014 r.) społeczność międzynarodowa obawia się wykorzystania przez Rosję kolejnych niestabilnych regionów w innych państwach obszaru poradzieckiego i intensyfikacji nastrojów separatystycznych. W obliczu potencjalnej możliwości pogłębienia problemu Naddniestrza, 22 czerwca 2018 r. Zgromadzenie Ogólne ONZ przyjęło projekt rezolucji przygotowanej przez Mołdawię we współpracy z Ukrainą, Rumunią, Gruzją, Kanadą, Łotwą, Estonią i Litwą w sprawie wycofania wojsk rosyjskich z NRM. Rezolucja została przyjęta głosami 64 państw (w tym m.in. Polski), 14 było jej przeciwnych (np. Armenia Białoruś, Wenezuela czy Syria), natomiast 83 państwa wstrzymały się od głosu. W treści rezolucji autorzy, powołując się m.in. na art. 2 Karty NZ, rezolucję 2625 z 24 października 1970 r. oraz postulowaną konstytucyjnie trwałą neutralność Mołdawii, uznają, że alokacja obcych sił zbrojnych na jej terytorium stanowi naruszenie suwerenności i integralności terytorialnej państwa. Wskazywano na wielokrotne apele Kiszyniowa wzywające do całkowitego usunięcia rosyjskich wojsk $\mathrm{z}$ terytorium Mołdawii, w tym podczas 24 . spotkania Rady Ministrów OBWE, które odbyło się w grudniu 2017 r. w Wiedniu, jak i zobowiązania przyjęte przez Federację Rosyjską w kwestii dokończenia wycofania sił i uzbrojenia z Republiki Mołdawii w określonym czasie, zgodnie z decyzją podjętą podczas szczytu OBWE w Stambule (1999). Podkreślono, że Grupa Operacyjna Wojsk Rosyjskich nie jest częścią wojskowego komponentu Wspólnej Komisji Kontrolnej, jednoczenie akcentując, że siły te przeprowadzają nielegalne ćwiczenia wojskowe wraz z formacjami separatystów ze wschodu, co stanowi bezpośrednie zagrożenie dla bezpieczeństwa oraz integralności Mołdawii, jak i podważa międzynarodowe wysiłki na rzecz pokojowego uregulowania konfliktu naddniestrzańskiego. Wobec powyższego wezwano Federację Rosyjską do zakończenia procesu usuwania rosyjskich żołnierzy i broni z terytorium Mołdawii. ONZ wyraziła również dalsze poparcie dla zaangażowania państw OBWE w zakończenie tego przedsięwzięcia, jak i zadeklarowała uwzględnienie tej kwestii podczas 73. Sesji Zgromadzenia Ogólnego (Rezolyutsiya, prinyataya General'noy Assambleyey 22 iyunya 2018 goda..., 2018). 


\section{STANOWISKO ROSJI I NADDNIESTRZA WOBEC AKTYWNOŚCI SPOŁECZNOŚCI MIĘDZYNARODOWEJ NA RZECZ USUNIĘCIA ROSYJSKICH SIŁ ZBROJNYCH}

MSZ parapaństwa w oficjalnych oświadczeniach odniosło się do przyjętej deklaracji na forum ONZ. Naddniestrzańskie Ministerstwo podkreśla, że architektem dokumentu, a także inicjatorem jego przyjęcia jest Republika Mołdawii, czyli strona konfliktu oraz aktywny uczestnik trójstronnej operacji pokojowej funkcjonującej na obszarze parapaństwa. Tyraspol interpretuje ten krok jako chęć zniszczenia poprawnie funkcjonującego formatu operacji, jedynie w celu usunięcia rosyjskich formacji. Przypomniano, że obecność rosyjskich sił zbrojnych jest regulowana m. in. deklaracją z 1992 r., a jakakolwiek reorganizacja formatu sił pokojowych może nastąpić dopiero na podstawie ostatecznego porozumienia Tyraspol-Kiszyniów, co potwierdza Wspólne oświadczenie prezydentów Federacji Rosyjskiej, Mołdawii i Naddniestrza z 18 marca 2009 r. Wobec tego MSZ wskazuje, że nie można podejmować decyzji o zmianie kształtu operacji pokojowej pod auspicjami Rosji, nie biorąc pod uwagę głosu Naddniestrza, wzywając jednocześnie mołdawskich decydentów do intensywniejszej pracy przy stole negocjacyjnym (Kommentariy Ministerstva inostrannykh del PMR v svyazi s rezolyutsiyey Genassamblei OON..., 2018). Czołowe persony naddniestrzańskiej sceny politycznej zgodnie popierają uczestnictwo sił rosyjskich, wskazując na ich dużą efektywność w zakresie deeskalacji sytuacji konfliktowej w regionie. Obecny prezydent quasi-państwa Wadim Krasnosielski podczas obchodów 26 rocznicy zainicjowania operacji pokojowej w Naddniestrzu (28 lipca 2018) podkreślał jej priorytetowość, wskazując, że dzięki zaangażowaniu rosyjskich sił pokojowych przez wiele lat nie doszło do rozmrożenia konfliktu i ponownego rozlewu krwi, deklarując niesłabnącą aprobatę ludności: „26 lat temu rosyjski mirotwórca wyciągnął pomocną dłoń do Naddniestrza. Nastał czas, kiedy naddniestrzański naród wyciąga pomocną dłoń do rosyjskiego mirotwórcy, udzielając pełnego wsparcia tutaj, na naddniestrzańskiej ziemi” („RIA Novosti”, 2018). Również minister spraw zagranicznych Witalij Ignatiew, zapytany podczas jednego z wywiadów o specjalne partnerstwo z Rosją w negocjacjach pokojowych, podkreślił, że Moskwa zrobiła bardzo dużo, aby stworzyć skuteczne mechanizmy ostatecznego rozwiązania konfliktu oraz to właśnie dzięki rosyjskiej operacji pokojowej mógł rozpocząć się polityczny dialog, a ludzie poczuli się bezpiecznie (Interv'yu Ministra inostrannykh del PMR Vitaliya Ignat'yeva..., 2018). 
W podobnym tonie MSZ odniosło się do deklaracji OBWE i NATO odnośnie wezwania Moskwy do usunięcia sił zbrojnych. Tyraspol wskazuje, że zważając na współpracę militarną Mołdawii z NATO, taka próba ingerowania członków tej organizacji w naddniestrzański proces pokojowy może zniwelować funkcjonowanie dotychczasowej struktury bezpieczeństwa tego obszaru, która w opinii decydentów naddniestrzańskich - jest efektywnym mechanizmem od dziesięcioleci. Równocześnie zaakcentowano, że OBWE jest integralną częścią procesu pokojowego nad Dniestrem (przedstawiciele we Wspólnej Komisji Kontrolnej), dysponuje informacjami o skuteczności mechanizmów pokojowych, których ważnym elementem są Siły Zbrojne Federacji Rosyjskiej. Wobec tego apel o usunięcie obecnego stanu pokoju, którego autorami są również państwa członkowskie OBWE, dowodzi podwójnego podejścia do kwestii Naddniestrza oraz podważa obiektywność stanowiska tej organizacji. Ministerstwo potwierdziło niezmienne poparcie dla obecnego formatu misji pokojowej oraz obecności sił rosyjskich, wskazując jednocześnie, że takie deklaracje są jedynie propagandowymi atakami, mającymi zniszczyć dialog międzynarodowy na rzecz uregulowania stosunków Tyraspol-Kiszyniów (Kommentariy MID PMR v svyazi s ocherednymi deklaratsiyami..., 2018). Naddniestrzańscy politycy podejmą wszelkie działania, które zapewnią dalsze stacjonowanie rosyjskich sił na tym obszarze, gdyż w ich percepcji tylko zbrojna obecność strategicznego partnera stanowi gwarancję dla przetrwania niezależnej względem Kiszyniowa NRM oraz minimalizuje ryzyko ponownych prób siłowego podporządkowania Naddniestrza Mołdawii. Co niezwykle istotne, ten punkt widzenia jest silnie popierany przez naddniestrzańskie społeczeństwo, w którym pamięć o wydarzeniach z 1992 r. jest wciąż żywa i niejednokrotnie odnawiana przez czołowych decydentów politycznych, stanowiąc jeden z elementów konsolidacji antyzachodnich nastrojów wśród mieszkańców. W przypadku jakiejkolwiek transformacji sił pokojowych i wyeliminowania czynnika rosyjskiego Tyraspol znajdowałby się w niekorzystnej sytuacji strategicznej, a stanowisko Kiszyniowa w trwających negocjacjach $\mathrm{w}$ formacie $5+2 \mathrm{z}$ pewnością byłoby bardziej stanowcze. Nie należy jednak zapominać, że efektywność zabiegów Mołdawii zdecydowanie obniża brak porozumienia w tej kwestii na najwyższych szczeblach władzy. Podczas rozmowy prezydentów Dodona i Krasnosielskiego w kwietniu 2018 r. prezydent Mołdawii wskazywał, że jednym z kluczowych tematów spotkania była obecna misja pokojowa. Jak przekonywał, wszystkie strony zaangażowane w jej funkcjonowanie wypełniają swoje zadania, dodając, że misja powinna być kontynuowana i za niewłaściwe uważa dywagacje na temat jej ograniczenia. To właśnie obecna misja 
pozwala na utrzymanie stabilności na prawym oraz lewym brzegu Dniestru, więc należy docenić jej rolę. Również w przeddzień rocznicy zainicjowania operacji pokojowej w Naddniestrzu Dodon w oficjalnym oświadczeniu podkreślał, że przez 26 lat jej funkcjonowania nie odnotowano ani jednego przypadku użycia siły między stronami konfliktu. Bez względu na głosy krytyczne płynące z kraju czy zagranicy nie ulega wątpliwości, że pokój nad Dniestrem został przywrócony dzięki dotychczasowej misji pokojowej.W opinii prezydenta, dopóki nie zostanie wypracowane polityczne rozwiązanie problemu Naddniestrza, nie powstaną mechanizmy utrzymywania pokoju w warunkach pokonfliktowych, mówić o likwidacji operacji będą jedynie populiści i prowokatorzy, którzy chcą zdestabilizować sytuację w Mołdawii (Po itogam proshedshey v Benderakh dvustoronney vstrechi rukovoditeli Pridnestrov'ya i Respubliki Moldova...2018). Te przykłady obrazują, że stanowisko Dodona jest wyraźnie przeciwstawne wobec zabiegów prozachodniego premiera Pavla Filipa podejmowanych na arenie międzynarodowej. Obóz proeuropejski widzi w rosyjskim zaangażowaniu jedną z głównych przeszkód w dynamizacji negocjacji pokojowych. Wsparcie Moskwy, którym dysponują separatystyczne władze, pomaga im w utrzymywaniu asertywności względem mołdawskich propozycji uregulowania konfliktu i perspektywy rychłej reintegracji Naddniestrza z Mołdawią.

Należy pamiętać o zdecydowanym stanowisku Moskwy w tej kwestii. Komentując uchwalenie rezolucji przez ZO ONZ, Dmitrij Polański, pierwszy zastępca stałego przedstawiciela Federacji Rosyjskiej przy ONZ, akcentował, że dla nikogo nie jest tajemnicą, że to właśnie Federacja Rosyjska jest gwarantem stabilności i pokoju w regionie. Ponadto akcentował dwugłos kierownictwa Mołdawii w tej kwestii. Równocześnie alarmował o zdecydowanym rozłamie wśród państw członkowskich ONZ. Co symptomatyczne, bezwzględna większość albo wstrzymała się od głosu, albo postanowiła nie uczestniczyć w głosowaniu nad rezolucją. Podobnie jak administracja tyraspolska Polański był rozczarowany postawą członków OBWE, którzy nie dostrzegają, że mołdawska inicjatywa rujnuje pozytywne efekty działań podjętych przez tę organizację. Co więcej, w ocenie przedstawiciela, ta rezolucja może obniżyć prestiż i reputację ONZ, gdyż decydenci podjęli kroki bez uwzględnienia opinii społeczeństwa parapaństwa („TASS”, 2018). Bez wątpienia Federacja Rosyjska skoncentruje się na opóźnianiu procesu całkowitego usunięcia sił z Naddniestrza, gdyż w przypadku finalizacji tego przedsięwzięcia straci narzędzie oddziaływania na linię polityczną Mołdawii. Brak pełnej kontroli nad całością terytorium stanowi istotną przeszkodę w potencjalnej integracji Kiszyniowa z NATO i UE, co jest zgodne z obraną 
strategią przez rosyjskich decydentów, którzy postrzegają Mołdawię jako część rosyjskiej strefy wpływów, będącej projekcją jej mocarstwowości i dominacji w przestrzeni poradzieckiej, pomniejszając tym samym wpływ Zachodu na politykę Kiszyniowa. Czynnikami sprzyjającymi rosyjskiej ingerencji w sprawy wewnętrzne Republiki Mołdawii są zabiegi prezydenta Dodona, który za cel strategiczny przyjął rewitalizację strategicznego partnerstwa Kiszyniów-Moskwa, a tym samym niewspierającego zabiegów mołdawskich stronnictw prozachodnich na arenie międzynarodowej.

\section{MIEJSCE NADDNIESTRZA I ROSYJSKICH SIŁ ZBROJNYCH NA JEGO OBSZARZE W NOWEJ STRATEGII OBRONY MOŁDAWII}

Warto zwrócić uwagę, że problem Naddniestrza oraz rosyjskiej obecności na jego obszarze stanowią niezwykle ważne wątki zatwierdzonej przez mołdawski parlament 3 października projektu nowej strategii obrony z 19 lipca 2018 r. Dokument Narodowa Strategia Obrony na lata 2018-2022 składa się z 6 rozdziałów: Kontekst strategiczny, Wizja strategiczna i cele, Kierunki działania, Zasoby narodowej obrony, Etapy i mechanizmy wdrażania, Monitoring, Ocena i sprawozdawczość. Już w samym wstępie strategii autorzy wskazują na to, że skoro od momentu odzyskania niepodległości przez Mołdawię jej krajowy system obronny został odpowiednio skonsolidowany, a jego rozwój postępował wraz z poszanowaniem europejskich zasad i wartości, to zbliżenie odzwierciedla akcentowanie w polityce zagranicznej integracji europejskiej, intensyfikacji i pogłębiania stosunków z NATO, jednocześnie szanując status neutralności Mołdawii. Mimo takiej deklaracji wśród najważniejszych interesów narodowych wskazano wprost integrację europejską, wkład w zapewnienie bezpieczeństwa międzynarodowego oraz reintegrację terytorialną. Przytoczone zapisy są niezwykle istotne z perspektywy uregulowania kwestii naddniestrzańskiej. Tyraspolska administracja bowiem zdecydowanie sprzeciwia się integracji państwa ze strukturami europejskimi, widząc w niej zagrożenie dla zachowania tożsamości ludności Naddniestrza oraz dalszego strategicznego partnerstwa $\mathrm{z}$ Rosją, co stanowi poważne zagrożenie dla przetrwania NRM.

Co więcej, punkt 13 rozdziału pierwszego, opisującego środowisko bezpieczeństwa państwa, wprost nawiązuje do Naddniestrza. Bezpośrednie zagrożenie dla realizacji interesów Kiszyniowa, z których część wymieniono wyżej, stanowi potencjał militarny sił separatystycznych, posiadających zewnętrzne wsparcie. 
Ponadto również zaakcentowano obecność rosyjskich formacji zbrojnych nielegalnie stacjonujących na tym obszarze wbrew zapisom konstytucyjnym Mołdawii. Ze względu na znaczny potencjał operacyjny tych grup stanowią one potencjalne narzędzie realizacji celów strategicznych Moskwy na lewym brzegu Dniestru; dodatkowym czynnikiem ryzyka jest skład broni i amunicji niedaleko wsi Kołbasna. Te dwie zmienne (potencjał separatystów i stacjonowanie sił rosyjskich) składające się na potencjał militarny regionu zostały zidentyfikowane jako główne zagrożenie dla suwerenności i integralności terytorialnej państwa (Postanovleniye Nr. 134 ot 19.07.2018 ob utverzhdenii Natsional'noy strategii oborony..., 2018). Wskazanie w jednym z najwyższych rangą dokumencie strategicznym Mołdawii Federacji Rosyjskiej jako zagrożenia dla jej bezpieczeństwa odzwierciedla konfrontacyjne nastawienie proeuropejskich środowisk politycznych, co z pewnością uniemożliwi efektywny dialog w formule $5+2$, zważywszy na kluczową rolę strony rosyjskiej w negocjacjach.

Ponadto mołdawscy decydenci dostrzegają wyraźne powiązanie między destabilizacją oraz konfliktem na Ukrainie a bezpieczeństwem Mołdawii (punkt 17), gdyż istnieje możliwość rozszerzenia obszaru niestabilności. Ugrupowania ekstremistyczne, niejako wzorując się na aktywności ukraińskich separatystów, mogą inicjować działania stanowiące elementy wojny hybrydowej na terytorium Mołdawii, co może przeszkodzić w realizacji jej strategicznych interesów, takich jak: pokojowe uregulowanie konfliktu naddniestrzańskiego oraz przywrócenie integralności terytorialnej, przy zachowaniu pełnej suwerenności (Postanovleniye Nr. 134 ot 19.07.2018 ob utverzhdenii Natsional'noy strategii oborony..., 2018). Przypuszczalnie taką aktywność naddniestrzańskich bojówek wspierałaby Federacja Rosyjska, której zaangażowanie było kluczowe podczas konfliktu w latach 90. XX w., będąc przyczyną sukcesu parapaństwa w starciu ze stroną mołdawską, rozpoczynając tym samym proces krzepnięcia państwowości tego podmiotu. $\mathrm{Z}$ tej perspektywy usunięcie rosyjskich formacji $\mathrm{z}$ tego regionu stanowi jeden z żywotnych interesów Kiszyniowa i chęć wzmocnienia bezpieczeństwa oraz samowładności państwa.

\section{ZAKOŃCZENIE}

Nie należy oczekiwać, że Federacja Rosyjska zdecyduje się na dynamizację procesu usuwania swoich formacji zbrojnych z obszaru Mołdawii w najbliższym czasie. Wspierając funkcjonowanie nieuznawanej NRM, posiada dogodne 
narzędzie nacisku na linię polityczną Kiszyniowa. W optyce rosyjskich interesów obecny, nieuregulowany status Naddniestrza jest najlepszym wariantem egzystencji tego podmiotu: brak sprawowania pełnej kontroli nad swym terytorium stanowi poważną przeszkodę dla Mołdawii w procesie zabiegania o członkostwo w Unii Europejskiej i tym samym utrzymuje ją w rosyjskiej strefie wpływów. Siły Zbrojne Federacji Rosyjskiej jawią się jako gwarant utrzymywania niezależności Naddniestrza względem Mołdawii, dlatego ich obecność jest jednoznacznie popierana przez tyraspolską administrację, która obawia się zwiększenia presji w toku negocjacji w sprawie statusu tego regionu w przypadku wycofania się rosyjskich formacji. W interpretacji naddniestrzańskich polityków reintegracja zbuntowanego regionu z państwem macierzystym może implikować atak na tożsamość narodową jego mieszkańców oraz osłabienie kooperacji z Federacją Rosyjską, która jest priorytetowa dla budowania dobrobytu naddniestrzańskiego społeczeństwa. Na korzyść zabezpieczenia rosyjskich interesów w tym regionie wpływa fakt braku harmonijnego i wspólnego stanowiska w tej kwestii czołowych decydentów Republiki Mołdawii. Dwutorowość linii politycznej osłabia skuteczność polityki Kiszyniowa wobec problemu Naddniestrza. Zdecydowany głos proeuropejskich stronnictw konsekwentnie postulujących usunięcie rosyjskich sił zbrojnych, dostrzegających w nich pogwałcenie suwerenności i integralności terytorialnej Mołdawii oraz potencjalne wyzwanie dla utrzymania pożądanego stanu bezpieczeństwa (ryzyko podobnej destabilizacji państwa jaka ma miejsce na Ukrainie), kontrastuje z linią polityczną kreowaną przez Igora Dodona. Prezydent kładzie akcent na odbudowę strategicznego partnerstwa Kiszyniów-Tyraspol, dlatego popiera dotychczasowy kształt operacji pokojowej w Naddniestrzu, podkreślając skuteczność rosyjskich sił oraz priorytetowe znaczenie Rosji jako architekta trwających negocjacji w sprawie ostatecznego uregulowania statusu Naddniestrza. Nie należy zapominać o zabiegach szeroko pojętej społeczności międzynarodowej, która wspiera stanowisko mołdawskich stronnictw proeuropejskich, jednak to wsparcie pozostaje jedynie w sferze deklaratywnej.

\section{BiBLIOGRAFIA:}

(1992). Soglasheniye o printsipakh mirnogo uregulirovaniya vooruzhennogo konflikta v Pridnestrovskom regione Respubliki Moldova, Moskva, 21 iyulya 1992 g. Pobrane z: http://www.peacekeeper.ru/ru/?action=view\&id=89\&module=pages.

(2014). Rezultaty Referendumov Pridnestrovskoy Moldavskoy Respubliki za period s 1989 g. po 2006 g. Pobrane z: https://www.cikpmr.com/index.php/o-vyborakh-i- 
-referendumakh/informatsiya-o-referendumakh/item/210-rezultaty-referendumov-pridnestrovskoj-moldavskoj-respubliki-za-period-s-1989-g-po-2006-g,\%20 dost\%C4\%99p:\%2011.11.2018\%20r.

(2018). Interv'yu Ministra inostrannykh del PMR Vitaliya Ignat'yeva rukovoditelyu "Laboratorii analiza pridnestrovskogo konflikta» Universiteta im. Luchiana Blaga (g. Sibiu, Rumyniya). Pobrane z: http://mfa-pmr.org/ru/zCh.

(2018). Kommentariy MID PMR v svyazi socherednymi deklaratsiyami, vedushchimi $k$ obostreniyu obstanovki vokrug Pridnestrov'ya. Pobrane z: http://mfa-pmr.org/ru/xqv. (2018). Po itogam proshedshey $v$ Benderakh dvustoronney vstrechi rukovoditeli Pridnestrov'ya i Respubliki Moldova sdelali zayavleniye dlya pressy. Pobrane z: http:// president.gospmr.org/press-sluzhba/novosti/po-itogam-proshedshey-v-benderahdvustoronney-vstrechi-rukovoditeli-pridnestrovjya-i-respubliki-moldova-sdelalizayavlenie-dlya-pressi.html.

(2018). Postanovleniye Nr. 134 ot 19.07.2018 ob utverzhdenii Natsionalnoy strategii oborony i Plana deystviy po vnedreniyu Natsionalnoy strategii oborony na 2018-2022 gody. Pobrane z: http://lex.justice.md/viewdoc.php?action=view\&view=doc\&i$\mathrm{d}=376667$ \&lang $=2$.

Leont'yeva, O., Yastrebchak, V. (2014). Politicheskiye elity Respubliki Moldova i Pridnestrovskoy Moldavskoy Respubliki: formirovaniye, genezis, vneshniye faktory. Problemy Natsionalnoy Strategii, 4(25), 86-102.

Lubicz-Miszewski, M. (2012). Geneza, przebieg i próby przezwyciężenia konfliktu o Naddniestrze. Zeszyty Naukowe WSOWL, 3, 121-138.

Miarka, A. (2016). Stanowisko Polski wobec oddziaływania Federacji Rosyjskiej na bezpieczeństwo Mołdawii. W: K. Czornik, M. Lakomy, M. Stolarczyk (red.). Stosunki Polski z mocarstwami w drugiej dekadzie XXI wieku (s. 229-247). Katowice: Wydawnictwo Fundacji na Rzecz Wspierania Edukacji i Rozwoju Samorządności wśród Młodzieży VIRIBUS UNITIS.

Miarka, A. (2018). Stosunki mołdawsko-rosyjskie w drugiej dekadzie XXI wieku. Przeglad Wschodnioeuropejski, 1,129-143.

Novik, A. (2013). Mirotvortsy - garant mira i stabil'nosti v Pridnestrov'ye. Pobrane z: http://peacekeeper.ru/ru/?module=news\&action=view\&id=16889.

Novosti Pridnestrov'ya. (2015). Perepis' naseleniya PMR. Pobrane z: http://newspmr. com/novosti-pmr/obshhestvo/15927.

Point.md. (2018). V svyazi s godovshchinoy nachala mirotvorcheskoy operatsii na Dnestre prezident vystupil sofitsial'nym zayavleniyem. Pobrane z: https://point.md/ ru/novosti/politika/v-sviazi-s-godovshchinoi-nachala-mirotvorcheskoi-operatsiina-dnestre-prezident-vystupil-s-ofitsialnym-zaiavleniem.

Serzhanova V. (2017). Powstanie Naddniestrzańskiej Republiki Mołdawskiej i jego implikacje. Studia Europejskie, 1, 253-269.

TASS. (22.06.2018). Genassambleya OON prinyala proyekt rezolyutsii Moldavii po vyvodu voyennykh RF iz Pridnestrov'ya,. ,,TASS”. Pobrane z: https://tass.ru/mezhdunarodnaya-panorama/5316532. 